\section{Pleural effusion as manifestation of temporal arteritis}

\author{
S Romero, P Vela, I Padilla, J Rosas, \\ C Martín, I Aranda
}

\begin{abstract}
Two patients with temporal arteritis who presented with pleural effusion are reported. Both had an exudate that responded to prednisolone treatment.
\end{abstract}

About $9 \%$ of patients with giant cell arteritis have prominent respiratory tract symptoms, and in $4 \%$ they are the initial manifestation. ${ }^{1}$ Pleural effusions are rare, only seven reports having been published, ${ }^{1-7}$ four of which give no details of the effusion. ${ }^{1-4}$ We describe two patients presenting with a pleural effusion.

\section{Case reports}

PATIENT 1

A 67 year old woman, previously symptom free, presented with a three month history of malaise, weight loss, shoulder girdle pain, frontoparietal headache, jaw claudication, cough, scanty sputum, and left pleuritic chest pain. On examination she had a tender, pulseless, slightly thickened right temporal artery, and decreased breath sounds and diminished vocal fremitus in the left lower chest. The haemoglobin concentration was $10.3 \mathrm{~g} / \mathrm{dl}$, white cell count $8.4 \times 10^{9} / 1(62 \%$ neutrophils, $30 \%$ lymphocytes, and $8 \%$ monocytes), and platelet count $520 \times 10^{9} / 1$. Her erythrocyte sedimentation rate was $86 \mathrm{~mm}$ in the first hour, and she had no antinuclear antibodies or rheumatoid factor. Sputum culture was negative for Mycobacterium tuberculosis. The chest radiograph and computed tomogram showed a small left pleural effusion. Fibreoptic bronchoscopy and abdominal computed tomography and ultrasound all gave normal results. Thoracocentesis yielded serous fluid that showed no specific features on microbiological and cytological examination. The pleural fluid white cell count was $0.6 \times 10^{9} / 1$ (43\% neutrophils, $12 \%$ lymphocytes, $10 \%$ macrophages, and $33 \%$ mesothelial cells), with no antinuclear antibodies or rheumatoid factor. Other serum and pleural fluid laboratory data are shown in the table. The pleural biopsy specimens showed atypical mesothelial hyperplasia arranged in nodules mixed with inflammatory cells (figure 1). A biopsy of the temporal artery showed myointimal proliferation with disruption of the internal elastic lamina, dense chronic inflammatory cellular infiltration, and giant cells.
After treatment with prednisone $(1 \mathrm{mg} / \mathrm{kg} \mathrm{a}$ day) there was rapid symptomatic improvement and after a week the left pleural shadow on the chest radiograph had virtually resolved. Two years later the patient was still taking corticosteroids ( $5 \mathrm{mg} /$ day) and was symptom free.

\section{PATIENT 2}

A previously fit 71 year old woman was admitted to hospital with a one month history of temporal headache, fatigue, and jaw claudication. A few days later she developed right pleuritic chest pain and a productive cough. On examination she had bilateral temporal artery thickening, though the pulses were preserved, and signs of a right pleural effusion. Laboratory findings included a haemoglobin concentration of $9.9 \mathrm{~g} / \mathrm{dl}$, a white cell count of $15 \times 10^{9} / 1$ (86\% neutrophils, $11 \%$ lymphocytes, and $3 \%$ monocytes), a platelet count of $69 \times 10^{9} / 1$, and an erythrocyte sedimentation rate of $126 \mathrm{~mm}$ in the first hour. Tests for antinuclear antibodies and rheumatoid factor gave negative results. The chest radiographs showed loss of the costophrenic angle and thickening of the oblique fissure on the right. Abdominal ultrasound examination showed no abnormality. Thoracocentesis yielded serous fluid that showed no specific features on microbiological or cytological examination. The pleural fluid white cell count was $3.2 \times 10^{9} / 1$ (45\% neutrophils, $5 \%$ lymphocytes, $8 \%$ hystiocytes, and $42 \%$ mesothelial cells); tests for antinuclear antibodies and rheumatoid factor gave negative results. Other laboratory data are shown in the table. A temporal artery biopsy specimen showed histological changes compatible with giant cell arteritis.

Treatment with prednisone ( $1 \mathrm{mg} / \mathrm{kg}$ a day) was started and caused rapid symptomatic and radiological improvement. She was still taking prednisone $(10 \mathrm{mg} /$ day $)$ and was symptom free when last seen 18 months later.

Laboratory data on the two patients (normal values in parentheses)

\begin{tabular}{|c|c|c|}
\hline Patient No: & 1 & 2 \\
\hline \multicolumn{3}{|l|}{ SERUM } \\
\hline Protein $(6 \cdot 4-8 \mathrm{~g} / \mathrm{dl})$ & $6 \cdot 2$ & 7 \\
\hline $\begin{array}{l}\text { Alkaline phosphatase (98-279 } \\
\text { U/1) }\end{array}$ & 629 & 643 \\
\hline $\begin{array}{l}\text { Lactate dehydrogenase (230- } \\
460 \mathrm{U} / \mathrm{l})\end{array}$ & 304 & 330 \\
\hline Cholesterol $(120-250 \mathrm{mg} / \mathrm{dl})$ & 176 & 187 \\
\hline $\begin{array}{l}\text { Carcinoembryonic antigen } \\
(<10 \mathrm{ng} / \mathrm{ml})\end{array}$ & 0.5 & $1 \cdot 2$ \\
\hline \multicolumn{3}{|l|}{ Complement } \\
\hline $\mathrm{C} 3(60-130 \mathrm{mg} / \mathrm{dl})$ & 120 & 214 \\
\hline $\mathrm{C} 4(16-42 \mathrm{mg} / \mathrm{dl})$ & 37 & 44 \\
\hline \multicolumn{3}{|l|}{ PLEURAL FLUID } \\
\hline Glucose $(\mathrm{mg} / \mathrm{dl})$ & 100 & 99 \\
\hline Protein $(\mathrm{g} / \mathrm{dl})$ & $3 \cdot 2$ & $4 \cdot 1$ \\
\hline Lactate dehydrogenase $(\mathrm{U} / \mathrm{l})$ & 170 & 1085 \\
\hline Amylase $(U / 1)$ & 32 & 87 \\
\hline Cholesterol (mg/dl) & 58 & 79 \\
\hline $\begin{array}{l}\text { Carcinoembryonic antigen } \\
\text { (ng/ml) }\end{array}$ & 0.5 & 2.5 \\
\hline \multicolumn{3}{|l|}{ Carbohydrate antigen } \\
\hline$(15-3 \mathrm{ng} / \mathrm{ml})$ & 5 & 20 \\
\hline$\alpha$ Fetoprotein $(\mathrm{IU} / \mathrm{ml})$ & $<1$ & $<1$ \\
\hline \multicolumn{3}{|l|}{ Complement } \\
\hline $\mathrm{C} 3(\mathrm{mg} / \mathrm{dl})$ & 36 & 92 \\
\hline $\mathrm{C4}(\mathrm{mg} / \mathrm{dl})$ & 18 & 26 \\
\hline
\end{tabular}




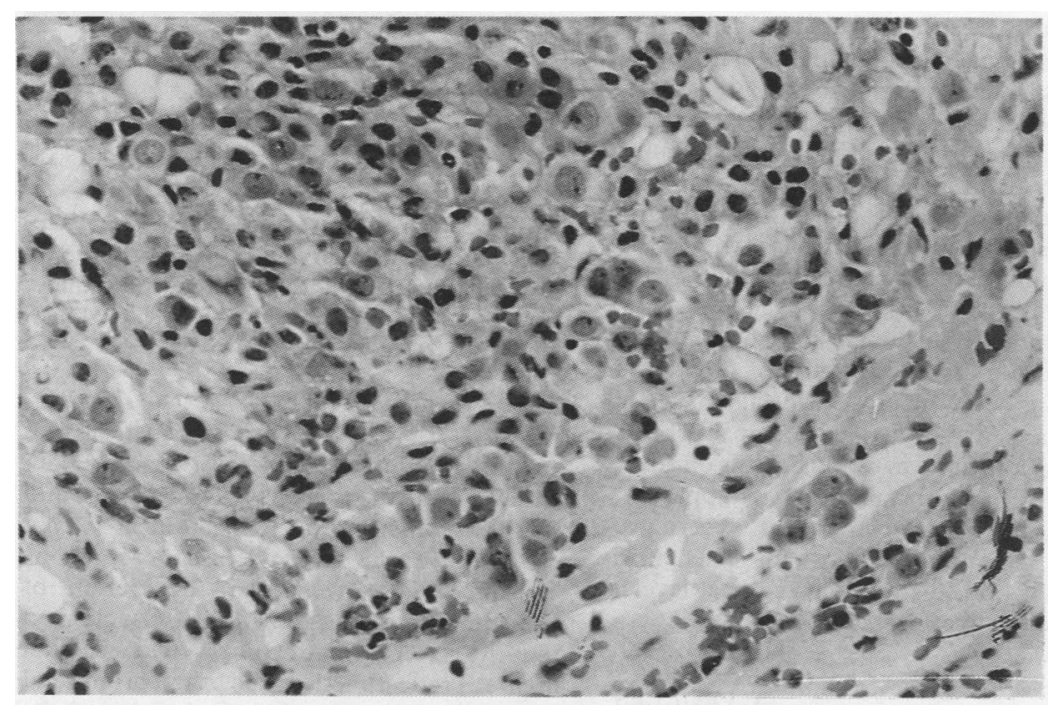

Pleural biopsy specimen with mesothelial hyperplasia: nodule of hyperplasic mesothelial cells mixed with inflammatory cells. (Haematoxylin and eosin.)

\section{Discussion}

Two patients with typical features of temporal arteritis were seen over a relatively short period of time with a pleural effusion at the time of diagnosis. Identification of the cause of a pleural exudate is not always easy and $20 \%$ of cases remain undiagnosed after conventional investigations, including cytology and biopsy. ${ }^{8}$

The characteristics of the pleural effusion are mentioned in three previous reports. ${ }^{5-7}$ The effusion in all three cases was an exudate with a high protein content, but no reference was made to lactate dehydrogenase activity. The pleural fluid in our two cases comply with Light's criteria for an exudate-namely, ratio of protein in pleural fluid/serum above 0.5 , a ratio for lactate dehydrogenase above $0 \cdot 6$, and/ or lactate dehydrogenase more than two thirds the upper limit of normal for serum lactate dehydrogenase. There was a predominance of polymorphonuclear cells in our patients as in two of the previous studies; the third study ${ }^{7}$ initially showed a predominance of lymphocytes and after numerous relapses a predominance of eosinophils, which could be due to repeated thoracocenteses. ${ }^{9}$ The concentration of glucose in the exudate, not mentioned in other studies, was similar to that in the serum in our patients.

In our cases tests for several tumour markers and non-organ specific antibodies gave negative and unhelpful results. The complement $\mathrm{C} 3$ and
C4 levels in the pleural fluid were relatively high but within the range found in our laboratory in fluid from patients with a pleural exudate due to various other causes, including neoplasms.

Histological study of the pleura in patients with effusions associated with temporal arteritis is limited to samples obtained by blind pleural biopsy. The changes found in two previous cases and in ours were non-specific, though our attention was drawn to the intense mesothelial reaction, which initially suggested the possibility of neoplasia. The presence of vascular changes in the pleura could not be excluded owing to the limited area sampled and the focal nature of this type of arteritis. In the only patient with a pleural effusion on whom a necropsy was carried out ${ }^{2}$ no reference was made to the histological appearances of the pleura.

The cytological findings in our patients were also non-specific. Although a low mesothelial cell count has been reported to suggest tuberculosis, ${ }^{10}$ a high count is not associated with any particular disease.

A coexisting disease as a cause of the effusion is very unlikely, in our cases as in others, as the patients had undergone thorough clinical investigation, which showed no other abnormality, and substantial lasting improvement occurred with corticosteroids.

1 Larson TS, Hall S, Hepper NGG, Hunder GG. Respiratory tract symptoms as a clue to giant cell arteritis. Ann Intern Med 1984;101:594-7.

2 Cooke WT, Cloake PCP, Govan ADT, Colbeck JC. Temporal arteritis: A generalized vascular disease. $Q J$ Med 1946;15:47-75.

3 Hamilton CR, Shelly WM, Tumulty PA. Giant cell arteritis: Including temporal arteritis and polymyalgia rheumatica. Medicine 1971;50:1-27.

4 Gallois P, Falconnet M, Dhers A, Plauchu G, Cavallero G, Cognet JB. Aspects cliniques de la maladie de Horton en médecine interne. A propos de 56 observations personnelles. Lyon Med 1979;241:837-42.

5 Routier G, Dutoit A, Carpentier M, et al. La maladie de Horton. Aspects actuels. J Sci Med (Lille) 1981;99:1-12.

6 Luthier F, Tourlière D, Rouchon JP, Divonne FF, Caplan $F$, Bardet $M$. Manifestations pleurales de la maladie de Horton. A propos d'un cas. Rev Méd Intern 1988;9:304-5.

7 Turiaf J, Valère PE, Gubler MC. Pleurésie récidivante au cours d'une arterite temporale. Poumon Coeur 1967;23: 633-51.

8 American Thoracic Society. Guidelines for thoracocentesis and needle biopsy of the pleura. Am Rev Respir Dis 1989; 140:257-8.

9 Adelman M, Albelda SM, Gottlieb J, Haponik EF. Diagnostic utility of pleural fluid eosinophilia. $\mathrm{Am} \mathrm{J} \mathrm{Med}$ 1984;77:915-20.

10 Spriggs AI, Boddington MM. Absence of mesothelial cells from tuberculous pleural effusions. Thorax 1968;15: $169-71$. 